\title{
Jambura Geoscience Review
}

P-ISSN: 2623-0682

Journal homepage: http://ejurnal.ung.ac.id/index.php/jgeosrev

\section{ANALYSIS OF SEAGRASS CONDITION USING SPECTRAL REFLECTION OF QUICKBIRD IMAGERY ON SARONDE ISLAND NORTH GORONTALO}

\author{
Daud Yusuf ${ }^{\mathrm{a}}$, Indrawan ${ }^{\mathrm{a}}$ \\ ${ }^{a}$ Department of Earth Science and Technology, Faculty of Mathematics and Natural Sciences, Universitas Negeri Gorontalo, \\ 96128 Indonesia
}

\section{ARTICLE INFO}

\section{Article history:}

Received: 18 December 2018

Accepted: 5 January 2019

Available Online: 29 January 2019

\section{Keywords:}

GIS, imagery classification, mapping, remote sensing

\section{Corresponding author:}

Daud Yusuf

Department of Earth Science and

Technology, Universitas Negeri

Gorontalo, Indonesia

Email: daud@ung.ac.id

\begin{abstract}
This study was encouraged by the importance of understanding the conditions of seagrass which becomes the source of food for many species of marine fish. Seagrass condition will indirectly affect the quantity and quality of fish obtained by fishermen who live in coastal areas. High-resolution imagery can simplify and accelerate data collection process of conditions of seagrass on the outer islands of Gorontalo Province. This study used digital remote sensing method using unsupervised classification and also assisted by the measurements of the transcule based on the pixel size that aims to detect and to match the information obtained from QuickBird imagery, to ultimately obtain information about seagrass condition. Seagrass with abundant/good condition can be found at station $1,3,4,5$, and 6 with an average cover up to $67,70 \%, 63,54 \%, 68,75 \%, 62,5 \%$, and $65,62 \%$ respectively. Meanwhile, seagrass with the less abundant/poor condition can be found at station 2 with an average cover up to $50 \%$ and at station 7 with an average cover up to $52,08 \%$. Distribution of seagrass on Saronde Island covers up to $6.9654 \mathrm{Ha}$. Seagrass with abundant/good condition covers 4,2025 Ha, and lowly abundant/poor seagrass covers 2,7629 Ha. Seagrass on Saronde Island is still in abundant/good condition with an average cover up to $61,45 \%$ and form mixed vegetation.
\end{abstract}

Copyright (C) 2019 JGeosREV-UNG This open access article is distributed under $a$ Creative Commons Attribution (CC-BY) 4.0 International license

\section{Introduction}

The existence of seagrass on the outer islands of northern Gorontalo can be found on several islands such as Mohinggito Island, Saronde Island, Dudepo Island and some other islands. Seagrass provides food and shelter for several marine species. Considering that seagrass provides enormous benefits for marine biota and human, its existence must be highly concerned. The Government, through Indonesian Study Institute (LIPI), has included the distribution of types, conditions, and potential of mangrove, coral reef and seagrass as one of their main programs in the field of marine affairs and fisheries. It is also strengthened by institutions that are responsible for preparing spatial data for all potential natural resources both on land and sea. The Geospatial Information Agency (BIG) is commissioned to supervise and provide signs and rules in terms of marine resources mapping. Universities in the related region are expected to become a partner in achieving these goals.

The Geographic Information System (GIS) integrated with remote sensing is able to identify and monitor and analyze natural resources and coastal areas. Those potentials of natural resources are seagrass, mangrove, coral ecosystems, and changes in coastal land use patterns. The use of remote sensing for the study of condition analysis and mapping of seagrass has many advantages when it comes to being compared with field survey method that can only cover narrow area (Hochberg \& Atkinson, 2003) and relatively takes longer time. Remote Sensing technology has advantages such as being able to record data and information widely, repeatedly and in more detail in detecting changes which happen in ecosystems 
(Mumby et al., 2004). It has many channels and bands, so it can be used to analyze various resources, able to reach areas that are relatively remote for human (Kutser et al., 2003). Data is obtained in digital format so it is easy to be analyzed using a computer and the price of the obtained information is relatively less expensive (Mumby et al., 1999)

Currently, digital satellite data has developed rapidly, with many choices of data offered, ranging from high to low spatial resolutions including Quickbird $(0,6 \mathrm{~m})$, Pleiades $(1 \mathrm{~m})$ Alos (Advanced and Observing Satellite) $(10 \mathrm{~m})$, SPOT $(2,5 \mathrm{~m})$, Aster (Advanced Spaceborne Thermal Emission and Reflection Radiometer) $(15 \mathrm{~m})$ and Landsat 8 (30 m) etc.

Study on mapping, analysis and monitoring of ecosystems in shallow waterways (corals, mangroves and seagrasses) has been carried out using satellite imagery data (Yamamuro et al., 2003), But in Indonesia, the mapping of conditions and types of seagrass using satellite imagery is rarely conducted. This sort of study already conducted on several locations, for example seagrass mapping on the coast of Bintan Island, Riau Islands (Kuriandewa \& Supriyadi, 2006); Kotania Bay and Pelitajaya, West Seram, Maluku (Supriyadi, 2009) Derawan Islands, East Kalimantan (Supriyadi \& Kuriandewa, 2008); LembehBitung, North Sulawesi (Supriyadi, 2008); Kema, North Minahasa; Pulau Island, Riau Islands; Tual, Southeast Maluku and Rote Island, East Nusa Tenggara.

Seagrass community is a key component in coastal ecosystems around the world (Hutomo \& Peristiwady, 1996). In addition to its intrinsic value, seagrass provides food and shelter for several types of marine fish and important commercial crustaceans (Gray et al., 1996). However, the existence of seagrass communities is almost varied in every coastal area, It is presumably due to the difference in coastal water characteristics.

The use of satellite imagery data to detect conditions and types of seagrass can be interpreted through the appearance of different tones and textures substrate (Larkum \& West, 1990). Mapping shallow water ecosystems using remote sensing could provide great benefits in coastal ecosystem management plan. The combination of Geographic Information Systems (GIS) and scoring methods of ecosystem components, such as types, conditions, and percentage of seagrass cover is very useful in the mapping of seagrass ecosystem condition, marine biological resources, and plans for integrated and sustainable management of coastal and marine areas.

Based on the previous study conducted in Nothern Gorontalo, this area has the potential of seagrass ecosystem which is evenly distributed in several islands. To know the development of this seagrass, it is necessary to obtain other spatial information related to the conditions of currently existing seagrass. This information becomes important because by understanding this information, the management and improvement of the sustainable seagrass ecosystem can be carried out and support a government program. Based on the facts and need for university involvement, it is necessary to conduct study "Analysis of Seagrass Condition Using Spectral Reflection of Quickbird Imagery on Saronde Island North Gorontalo"

\section{Methodology}

\subsection{Time and site of the study}

This study was conducted on Saronde Island, District of Kwandang, North Gorontalo Regency, Gorontalo from February to April 2016. Saronde Island is located on the Sulawesi Sea. It is astronomically located at $\mathrm{N} 00^{\circ} 55^{\prime} 56.0^{\prime \prime}-\mathrm{N} 00^{\circ} 55^{\prime} 23.3^{\prime \prime}$ and E $122^{\circ} 51$ '30"- E 122 $52^{\prime} 10^{\prime \prime}$, and administratively located in District of Kwandang, North Gorontalo Regency. Saronde Island shares its border with Sulawesi Sea in the north. Saronde Island is a part of Ponelo Islands which is about \pm 12 miles from Kwandang Harbor which is very potential in terms of tourism since it is filled with pine and coast with beautiful white sand, the area of Saronde is $\pm 4 \mathrm{Ha}$, with flat and hilly topography and flatconvex slopes.

\subsection{Tools and materials of the study}

Satellite imagery data used in this study was Quickbird Satellite Imagery recorded in 2016 with a spatial resolution of 0,6 meters combined with RBI Map Sheet of Kwandang which then analyzed using SAGA GIS to classify basic marine objects like seagrass in reef flats. Every map in this study created with QGIS. Imagery classification and creation of map were conducted in Geography Laboratory, Universitas Negeri Gorontalo. 


\subsection{Sources of data}

Primary data of this study is the conditions of seagrass obtained through imagery interpretation and field survey. Secondary data that supports this study are RBI Map, Central Statistics Agency (BPS) data and journals related to this study.

\subsection{Data acquisition}

The number of observation stations was designed as many as 7 stations, those stations were determined using purposive sampling techniques that had previously been pre-determined through unsupervised classification on seagrass. Field survey was conducted by visiting every station on study site to obtain data about actual seagrass condition using square transect method.

\subsection{Data Analysis}

The distribution of seagrass on Saronde Island was calculated through several stages, by conducting the classification stages of satellite imagery. The first step in image processing is to correct the Quickbird satellite imagery using radiometric and geometric correction. Radiometric correction conducted to correct pixel value, which is usually considering atmospheric disturbance factors as the main source of

(a)

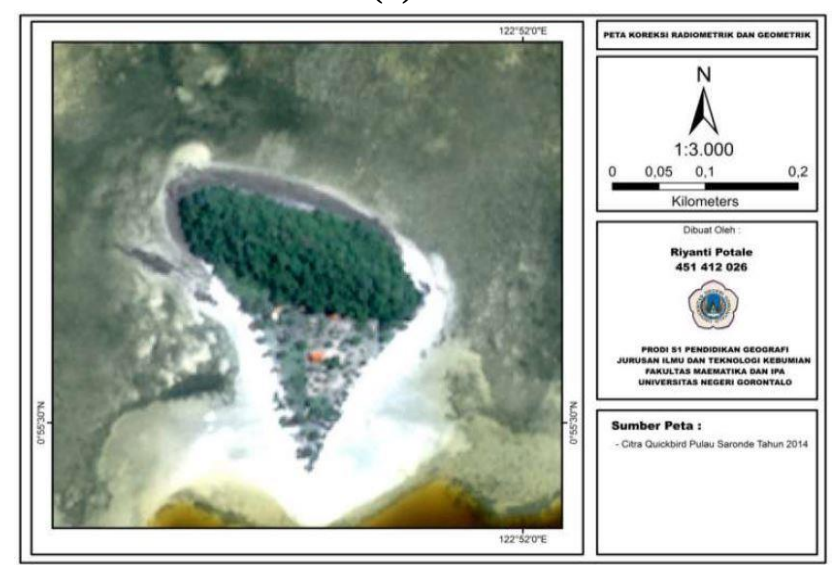

(c)

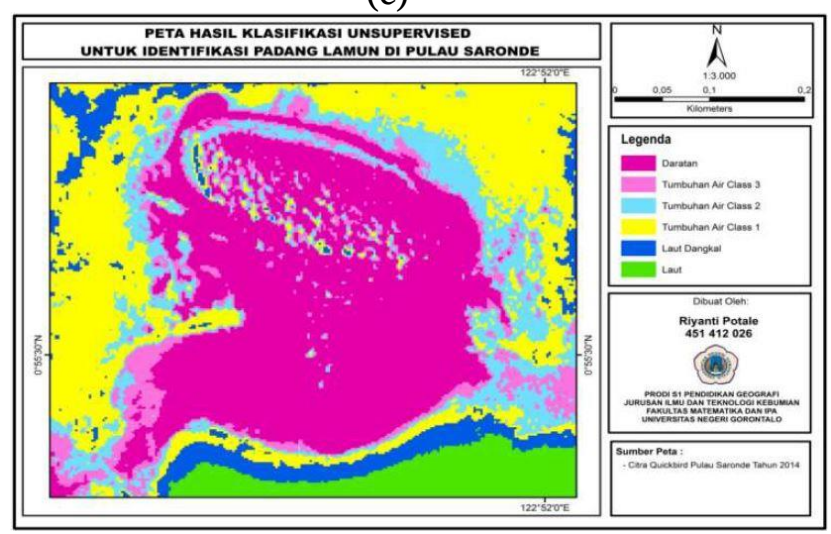

(e)

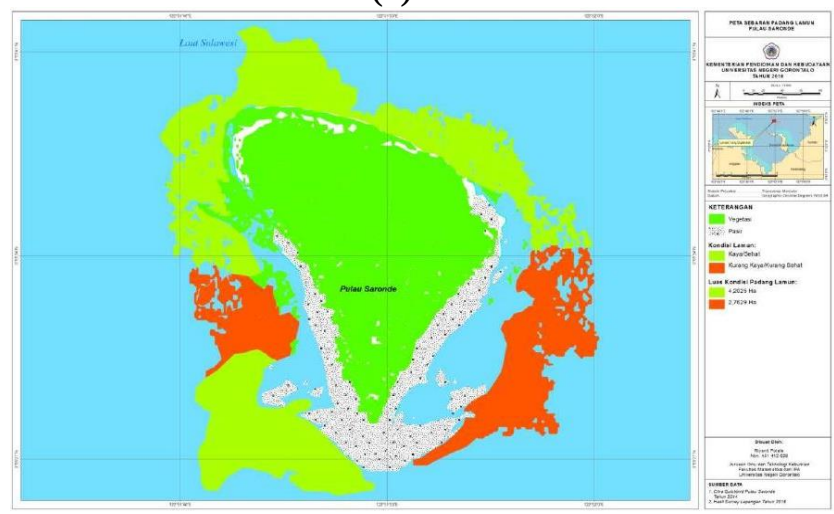

(b)

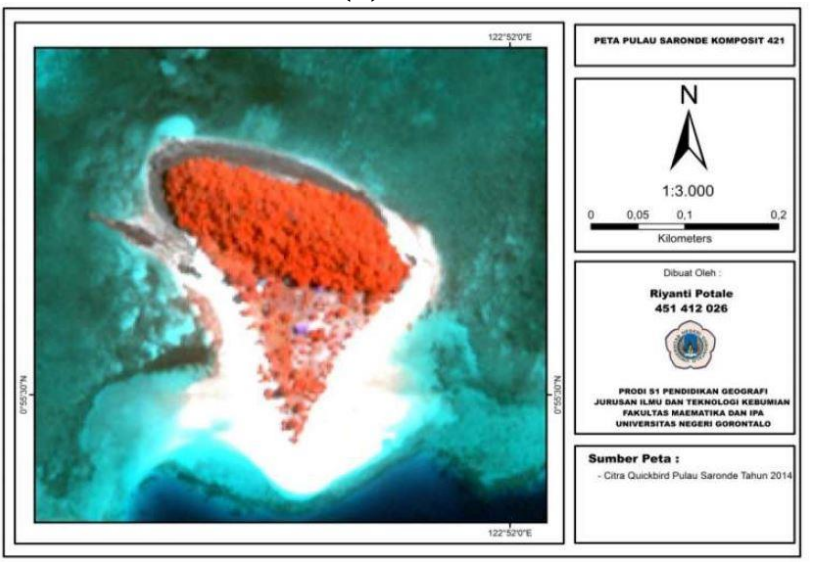

(d)

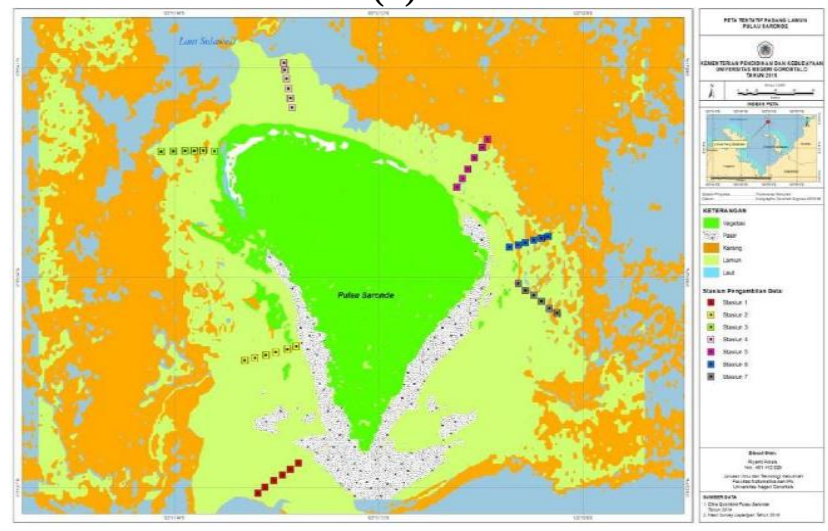

Figure 1. (a) The result of radiometric and geometric correction, (b) Composite 421 Imagery map, (c) The result of unsupervised classification, (d) Tentative map (e) Reinterpretation result. 
Table 1. Condition of seagrass on Saronde Island based on seagrass cover rate.

\begin{tabular}{lll}
\hline Station & Rate of Segrass Cover (\%) & Condition \\
\hline 1 & 67,70 & Abundant/Good \\
2 & 50 & Less Abundant/Poor \\
3 & 63,54 & Abundant/Good \\
4 & 68,75 & Abundant/Good \\
5 & 62,5 & Abundant/Good \\
6 & 65,62 & Abundant/Good \\
7 & 52,08 & Less Abundant /Poor \\
\hline
\end{tabular}

errors. Geometric correction is conducted to project the image and to match the coordinate system that is used by the image so that the image can be processed into the next step.

The corrected result was then cropped in accordance with the site of the study (Figure 1a). Cropping was conducted to focus the study area so as to facilitate imagery analysis and the analysis can be conducted in a more effective way. The correction results are changed to composite 421 (Figure 1b) to make the distribution of seagrass more clearly viewed through tone and color on the image. Furthermore, imagery classification was conducted using unsupervised classification (Figure 1c). Determination of sampling points was conducted by using squared transect method which was sampled on the specified transect, each transect measuring $50 \mathrm{~cm}$ x $50 \mathrm{~cm}$ with 10 meters separating each station.

In this study the sampling of seagrass cover on Saronde Island conducted in 7 stations, each station contains 6 sampling points, so all of them were 42 sampling points. The results of classification and determination of sampling points that have been conducted generate a tentative map (Figure 1d). Tentative data or information that has been obtained then clarified through field survey. Data about seagrass cover then calculated with the following equations (Rahmawati et al., 2014):

Seagrass cover $=\frac{\text { sum of seagrass cover (4 squares) }}{4}$

Rate of seagrass cover $=\frac{\text { sum of seagrass cover of all transect }}{\text { The sum of squares of all transects }}$

\section{Results and Discussion}

In general, the distribution of seagrass condition on Saronde Island is still in abundant/good condition, as seen from the average of seagrass cover $61,45 \%$ based on the criteria for seagrass (Minister of Environment Decree No. 200 of 2004). Seagrass on Saronde Island forms mixed vegetation that consists of several types of seagrass that live in one substrate. Through imagery interpretation and the result of the field survey, it can be known from figure 1e that the distribution of seagrass on Saronde Island covers up to $6,96 \mathrm{Ha}$, where seagrass with abundant/good conditions covers 4,20 $\mathrm{Ha}$, and seagrass with less abundant/poor condition cover 2,76 Ha. The result of re-interpretation shows that the distribution of seagrass on Saronde Island is distributed evenly all around the island.

Seagrass with abundant/good condition can be found at station 1,3,4,5, and 6 with an average cover up to $67,70 \%, 63,54 \%, 68,75 \%, 62,5 \%$, and $65,62 \%$ respectively (Table 1 ). Meanwhile, seagrass with the less abundant/poor condition can be found at station 2 with an average cover up to $50 \%$. Seagrass in this station is mainly damaged by the receding of sea water. When sea water recedes, seagrass in this station is very likely to be trampled by visitors of Saronde Island which then cause terrible damage to the seagrass in this station. Seagrass with the less abundant/poor condition can also be found at station 7 with an average cover up to $52,08 \%$. Seagrass in this station often gets damaged by uncontrolled boat parking and visitor activity like swimming.

\section{Conclusion}

Distribution of seagrass on Saronde Island covers up to 6, 9654 Ha. Seagrass with abundant/good condition covers 4, $2025 \mathrm{Ha}$, and lowly abundant/poor seagrass covers 2, $7629 \mathrm{Ha}$. Seagrass on Saronde Island is still in abundant/good condition with an average cover up to $61,45 \%$ and form mixed vegetation. Saronde Island contains an enormous wealth of marine coastal resources, both in terms of 
economy and aesthetics. Saronde Island needs effective maintenance in order to maintain and to preserve its marine resources wealth, particularly in the case of seagrass.

\section{Acknowledgments}

First of all, we would like to express our gratitude to Almighty God for all blessings that have always been given to us. We would also like to say thanks to all staffs of Geography Laboratory Universitas Negeri Gorontalo especially to Karina Meiyanti Maulana and Yemima Otoluwa who had given us a significant favor during this study. Lastly, we would like to say thanks to everyone who had been willing to cooperate with us during the completion of this study that is improbable for us to mention one by one. We truly realize that this study would not be successful without their very kindly cooperation.

\section{References}

Gray, C. A., McElligott, D. J., \& Chick, R. C. (1996). Intra- and inter-estuary differences in assemblages of fishes associated with shallow seagrass and bare sand. Marine and Freshwater Research. https://doi.org/10.1071/MF9960723

Hochberg, E. J., \& Atkinson, M. J. (2003). Capabilities of remote sensors to classify coral, algae, and sand as pure and mixed spectra. Remote Sensing of Environment. https://doi.org/10.1016/S00344257(02)00202-X

Hutomo, M., \& Peristiwady, T. (1996). Diversity, abundance and diet of fish in the seagrass beds of Lombok Island, Indonesia. In Seagrass Biology: Proceedings of an International Workshop'.(Eds J. Kuo, RC Phillips, DI Walker and H. Kirkman.) pp (pp. 205-212).

Kuriandewa, T. E., \& Supriyadi, I. H. (2006). Seagrass mapping in East Bintan coastal area, Riau archipelago, Indonesia. Coastal Marine Science, 30(1), 154-161.

Kutser, T., Dekker, A. G., \& Skirving, W. (2003). Modeling spectral discrimination of Great Barrier Reef benthic communities by remote sensing instruments. Limnology and Oceanography. https://doi.org/10.4319/1o.2003.48.1_part_2.0497

Larkum, A. W. D., \& West, R. J. (1990). Long-term changes of seagrass meadows in Botany Bay, Australia. Aquatic Botany. https://doi.org/10.1016/0304-3770(90)90064-R

Mumby, P. J., Edwards, A. J., Arias-González, J. E., Lindeman, K. C., Blackwell, P. G., Gall, A., ... Llewenyn, G. (2004). Mangroves enhance the biomass of coral reef fish communities in the Caribbean. Nature. https://doi.org/10.1038/nature02286

Mumby, P. J., Green, E. P., Edwards, A. J., \& Clark, C. D. (1999). The cost-effectiveness of remote sensing for tropical coastal resources assessment and management. Journal of Environmental Management. https://doi.org/10.1006/jema.1998.0255

Rahmawati, S., Hutomo, M., \& Azkab, M. H. (2014). Panduan Monitoring Padang Lamun. (M. Hutomo \& A. Nontji, Eds.). Bogor: COREMAP - CTI Lembaga Ilmu Pengetahuan Indonesia. Retrieved from coremap.or.id/downloads/Lamun-27022015.pdf

Supriyadi, I. H. (2008). Pemetaan kondisi lamun dan bahaya ancamannya dengan menggunakan citra satelit ALOS di pesisir selatan, Bitung Manado, Sulawesi Utara. Oseanologi Dan Limpnologi Di Indonesia, 34(3), 556-459.

Supriyadi, I. H. (2009). Pemetaan lamun dan biota asosiasi untuk identifikasi daerah perlindungan lamun di Teluk Kotania dan Pelitajaya. Oseanologi Dan Limnologi Di Indonesia, 45(2), 167-183.

Supriyadi, I. H., \& Kuriandewa, T. E. (2008). Seagrass Distribution at Small Islands: Derawan Archipelago, East Kalimantan Province, Indonesia. Oseanologi Dan Limpnologi Di Indonesia, 34(1), 83-99.

Yamamuro, M., Nishimura, K., Kishimoto, K., Nozaki, K., Kato, K., Negishi, A., ... Fukuoka, K. (2003). Mapping tropical seagrass beds with an underwater remotely operated vehicle (ROV). Japan International Marine Science and Technology Federation. Japan International Marine Science and Technology Federation. 
Appendix. Field survey result

\begin{tabular}{|c|c|c|c|c|}
\hline Station & Coordinates & $\begin{array}{l}\text { Sampling Points } \\
\text { (Squared Transect) }\end{array}$ & Distance (M) & $\begin{array}{l}\text { Rate of } \\
\text { Seagrass Cover }\end{array}$ \\
\hline \multirow{6}{*}{1} & \multirow{6}{*}{$\begin{array}{l}\mathrm{N}=00^{\circ} 55^{\prime} 27,5^{\prime \prime} \\
\mathrm{E}=122^{\circ} 51^{\prime} 50,2^{\prime \prime}\end{array}$} & 1 & 0 & 75 \\
\hline & & 2 & 10 & 68.5 \\
\hline & & 3 & 20 & 56.25 \\
\hline & & 4 & 30 & 56.25 \\
\hline & & 5 & 40 & 50 \\
\hline & & 6 & 50 & 100 \\
\hline \multirow{6}{*}{2} & \multirow{6}{*}{$\begin{array}{l}\mathrm{N}=00^{\circ} 55^{\prime} 27,5^{\prime \prime} \\
\mathrm{E}=122^{\circ} 51^{\prime} 50,2^{\prime \prime}\end{array}$} & 1 & 0 & 18.75 \\
\hline & & 2 & 10 & 37.5 \\
\hline & & 3 & 20 & 50 \\
\hline & & 4 & 30 & 68.75 \\
\hline & & 5 & 40 & 62.5 \\
\hline & & 6 & 50 & 62.5 \\
\hline \multirow{6}{*}{3} & \multirow{6}{*}{$\begin{array}{l}\mathrm{N}=00^{\circ} 55^{\prime} 27,5^{\prime \prime} \\
\mathrm{E}=122^{\circ} 51^{\prime} 50,2^{\prime \prime}\end{array}$} & 1 & 0 & 50 \\
\hline & & 2 & 10 & 56.25 \\
\hline & & 3 & 20 & 50 \\
\hline & & 4 & 30 & 68.75 \\
\hline & & 5 & 40 & 68.75 \\
\hline & & 6 & 50 & 87.5 \\
\hline \multirow{6}{*}{4} & \multirow{6}{*}{$\begin{array}{l}\mathrm{N}=00^{\circ} 55^{\prime} 27,5^{\prime \prime} \\
\mathrm{E}=122^{\circ} 51^{\prime} 50,2^{\prime \prime}\end{array}$} & 1 & 0 & 62.5 \\
\hline & & 2 & 10 & 56.25 \\
\hline & & 3 & 20 & 56.25 \\
\hline & & 4 & 30 & 75 \\
\hline & & 5 & 40 & 81.25 \\
\hline & & 6 & 50 & 81.25 \\
\hline \multirow{6}{*}{5} & \multirow{6}{*}{$\begin{array}{l}\mathrm{N}=00^{\circ} 55^{\prime} 27,5^{\prime \prime} \\
\mathrm{E}=122^{\circ} 51^{\prime} 50,2^{\prime \prime}\end{array}$} & 1 & 0 & 31.25 \\
\hline & & 2 & 10 & 62.5 \\
\hline & & 3 & 20 & 75 \\
\hline & & 4 & 30 & 68.75 \\
\hline & & 5 & 40 & 56.25 \\
\hline & & 6 & 50 & 81.25 \\
\hline \multirow{6}{*}{6} & \multirow{6}{*}{$\begin{array}{l}\mathrm{N}=00^{\circ} 55^{\prime} 27,5^{\prime \prime} \mathrm{E}= \\
122^{\circ} 51^{\prime} 50,2^{\prime \prime}\end{array}$} & 1 & 0 & 43.75 \\
\hline & & 2 & 10 & 68.75 \\
\hline & & 3 & 20 & 75 \\
\hline & & 4 & 30 & 56.25 \\
\hline & & 5 & 40 & 62.5 \\
\hline & & 6 & 50 & 87.5 \\
\hline \multirow{6}{*}{7} & \multirow{6}{*}{$\begin{array}{l}\mathrm{N}=00^{\circ} 55^{\prime} 27,5^{\prime \prime} \mathrm{E}= \\
122^{\circ} 51^{\prime} 50,2^{\prime \prime}\end{array}$} & 1 & 0 & 43.75 \\
\hline & & 2 & 10 & 37.5 \\
\hline & & 3 & 20 & 56.25 \\
\hline & & 4 & 30 & 43.75 \\
\hline & & 5 & 40 & 50 \\
\hline & & 6 & 50 & 81.25 \\
\hline \multicolumn{4}{|c|}{ Rate of seagrass cover (\%) from all stations } & 61.45 \\
\hline
\end{tabular}

